\title{
Epicardial Lipoma
}

National Cancer Institute

\section{Source}

National Cancer Institute. Epicardial Lipoma. NCI Thesaurus. Code C6742.

A rare benign adipose tissue neoplasm of the epicardium of the heart. 